\title{
Caffeic Acid Phenethyl Ester Inhibits Proliferation and Migration, and Induces Apoptosis in Platelet-Derived Growth Factor-BB-Stimulated Human Coronary Smooth Muscle Cells
}

\author{
Hung Chin Ho ${ }^{a, b}$ Ho Ching Chang ${ }^{a}$ Chih Tai Ting ${ }^{b}$ Chan Yen Kuo ${ }^{a}$ \\ Vivian C. Yang ${ }^{a}$ \\ ${ }^{a}$ Department of Life Science, Tunghai University, and ${ }^{b}$ Cardiovascular Center, Taichung Veterans General Hospital, \\ Taichung, Taiwan, ROC
}

\section{Key Words}

Caffeic acid phenethyl ester $\cdot$ Human coronary smooth muscle cells $\cdot$ Apoptosis - Antiproliferative effect .

Antimigratory effect

\begin{abstract}
Background/Aims: Restenosis after a percutaneous coronary intervention $(\mathrm{PCl})$ during treatment for coronary artery disease is closely related to smooth muscle cell (SMC) proliferation and migration. In this study, we investigated the effects of caffeic acid phenethyl ester (CAPE) and its underlying mechanism on human coronary SMCs (HCSMCs) after platelet-derived growth factor-BB (PDGF-BB) stimulation in vitro. Methods and Results: The results showed that CAPE inhibited proliferation and migration, and induced apoptosis. Concomitantly, CAPE inhibited activation of AKT1, MEK1 and ERK1/2 signaling molecules at 10-60 min after CAPE treatment. As revealed by flow cytometry, DNA fragmentation and TUNEL assay, the cells accumulated at the sub- $\mathrm{G}_{1}$ phase, and cell apoptosis was observed after 30 and $90 \mu \mathrm{M}$ CAPE treatment for $72 \mathrm{~h}$. CAPE triggered the release of cytochrome $\mathrm{c}$ from mitochondria to cytosol, upregulated the proapoptotic gene Bax and downregulated the antiapoptotic gene $\mathrm{BCl}-2$. Upregulation of caspase- 9 and caspase-3 indi-
\end{abstract}

\section{KARGER}

Fax +41613061234 E-Mail karger@karger.ch www.karger.com
(C) 2011 S. Karger AG, Basel

$1018-1172 / 12 / 0491-0024 \$ 38.00 / 0$

Accessible online at:

www.karger.com/jvr cated that CAPE precipitated the mitochondrion-dependent apoptotic signaling pathway. Conclusions: These results provide a molecular explanation for the antiproliferation, antimigration and proapoptotic effects of CAPE on HCSMCs after PDGF-BB stimulation.

Copyright $\odot 2011$ S. Karger AG, Basel

\section{Introduction}

Percutaneous coronary intervention (PCI) is the major therapeutic strategy for coronary artery disease. However, restenosis after PCI still challenges both the vascular biologist and interventional cardiologist. Restenosis is associated with vascular smooth muscle cell (SMC) proliferation and migration as well as high resistance to apoptosis in the intima, reflecting failure of the apoptotic pathway in the cells $[1,2]$. SMCs re-enter the cell cycle and become able to migrate due to release of cytokines and growth factors from recruited platelets and impaired endothelial cells in

Dr. Vivian C. Yang

Department of Life Science, Tunghai University

181, Section 3, Taichung Harbor Road

Taichung 407, Taiwan (ROC)

Tel. +886 42359 0121, ext. 32447, E-Mail vcyang@ thu.edu.tw

Co-corresponding author: Dr. Chan Yen Kuo

Department of Life Science, Tunghai University

181, Section 3, Taichung Harbor Road

Taichung 407, Taiwan (ROC)

Tel. +886 42359 0121, ext. 32448, E-Mail g902302@yahoo.com.tw 
the vessel walls following injury [3]. Among the various growth factors that can trigger SMC proliferation and migration, platelet-derived growth factors (PDGF)-BB possess the most potent mitogenic and inflammatory effects [4]. PDGF-BB can activate several signaling cascades, including mitogen-activated protein kinases (MAPKs) and phosphatidylinositol 3-kinase (PI3K)/AKT [5]. It has been reported that in animals, increased levels of PDGF-BB result in neointimal thickening [6].

In the past, various pharmacologic tools, such as rapamycin/sirolimus-coated stents, have demonstrated potential in overcoming restenosis [7]. However, the problems have not been completely resolved. Recently, natural compounds rich in polyphenolic constituents have been a new field of research for preventing restenosis due to evidence of a decreasing risk of cardiovascular disease in epidemiological studies [8, 9]. Caffeic acid phenethyl ester (CAPE), the active component of propolis, has antioxidative, antiinflammatory antiproliferative and antineoplastic biological properties $[10,11]$. We have demonstrated that using a local infusion system, CAPE was able to reverse iliac artery intimal thickening in rabbits after balloon angioplasty [12]. It has been reported that CAPE may lead to a reduction of neointima formation by inhibiting nuclear transcription factor kappa-B (NF- $\mathrm{\kappa B}$ ) activation after balloon angioplasty in a rat model [13]. The underlying mechanism, however, is still not clear. In this study, we investigated the effects of CAPE on HCSMCs after PDGF-BB stimulation in vitro in order to mimic a post-PCI PDGF$\mathrm{BB}$-releasing condition. Meanwhile, we have examined the expression of signaling molecules and apoptotic target genes in cells to explore the underlying mechanisms of the effects of CAPE on PDGF-BB-stimulated HCSMCs.

\section{Methods}

\section{Cell Culture}

HCSMCs (PromoCell GmbH, Heidelberg, Germany) were cultured at $37^{\circ} \mathrm{C}$ in T-25 flasks (Corning Glassworks, Corning, N.Y., USA) in Medium 199 (Gibco, New York, N.Y., USA) supplemented with $10 \%$ fetal bovine serum and penicillin-streptomycin ( $50 \mathrm{U} / \mathrm{ml}$, Sigma, St. Louis, Mo., USA) in a $5 \% \mathrm{CO}_{2} / 95 \%$ air atmosphere. The culture medium was replaced every 2 days. Once the cells reached $70-80 \%$ confluence, they were trypsinized and seeded on 6-well plastic dishes for the following experiments. Passage 3-9 HCSMCs were used in the experiment.

\section{Cell Growth Assay}

HCSMCs were seeded on 6-well plastic dishes at a concentration of $1 \times 10^{5}$ per well. Prior to the experiment, $60-70 \%$ confluence cells were washed twice with phosphate-buffered saline (PBS), stimulated with PDGF-BB (10 $\mu \mathrm{M})$ (Sigma) [14] and incu- bated with serum medium supplemented with various concentrations $(0,3,10,30,90 \mu \mathrm{M})$ of CAPE (Sigma) for 0, 6, 12, 24, 48 and $72 \mathrm{~h}$, respectively. Cells were then stained with trypan blue and cell numbers were counted under an inverted microscope. Data are presented as the means \pm SDs of 3 replicates from 6 separate experiments.

\section{Cell Migration Assay}

HCSMCs were plated at an initial density of $1 \times 10^{5}$ cells $/ \mathrm{ml}$ to form a monolayer. During the last $4 \mathrm{~h}$, cytosine $\beta$-D-arabinofuranoside (Sigma) was added at a final concentration of $4 \mu \mathrm{M}$ to prevent SMC proliferation. Cells were washed twice with PBS and incubated with $10 \mu \mathrm{M}$ PDGF-BB and serum medium containing various concentrations $(0,3,10,30$ and $90 \mu \mathrm{M})$ of CAPE for 0,6 , $12,24,48$ and $72 \mathrm{~h}$, respectively. Then, cells were wounded by scraping with a pipette tip to make an approximately $400-\mu \mathrm{m}$ gap in the cell monolayer. The images of cell migration were observed at different time intervals and photographed at 5 marked locations on each dish using a phase-contrast microscope. The number of migrated cells was counted and averaged. All experiments were carried out in triplicate and repeated at least 6 times.

\section{Western Blot Analysis}

HCSMCs were treated with $10 \mu \mathrm{M}$ PDGF-BB at various concentrations of CAPE $(0,3,10,30,90 \mu \mathrm{M})$ for various time intervals. After incubation, the cells were washed 3 times with PBS and lysed with RIPA lysis buffer (Pierce, Rockford, Ill., USA) with a Protease Inhibitor Cocktail Kit (Thermo, Rockford, Ill., USA) at $4^{\circ} \mathrm{C}$ for $30 \mathrm{~min}$. The lysates were then centrifuged at $10,000 \mathrm{~g}$ at $4^{\circ} \mathrm{C}$ to obtain solubilized cellular proteins. The supernatant protein concentration was measured with a bicinchoninic acid protein assay (Pierce). Proteins $(50 \mu \mathrm{g})$ were separated by 10 or $12 \%$ SDS-PAGE and electrotransferred to a polyvinylidene fluoride membrane. Blots were probed with phosphorylated rabbit antihuman AKT1 (1:1,000, v/v), phosphorylated rabbit anti-human MEK (1:1,000), phosphorylated rabbit anti-human-extracellular signal-regulated kinase (ERK) (1:1,000), phosphorylated rabbit anti-human-ІкB (1:1,000), mouse anti-human caspase-8 (1:1,000, v/v), rabbit anti-human caspase- 9 , rabbit anti-human caspase- 3 (Cell Signaling Technology, Boston, Mass., USA), followed by HRP-conjugated goat anti-rabbit IgG (1:5,000, v/v) (Zymed, South San Francisco, Calif., USA) or HRP-conjugated goat antimouse IgG (1:5,000, v/v) (Zymed). After washing with PBS containing $0.5 \%$ Tween-20, peroxidase activity was assessed using enhanced chemiluminescence (Perkin-Elmer Life Science, Boston, Mass., USA). For an internal control, the same membrane was reprobed with a monoclonal antibody directed against $\beta$-actin $(1: 10,000, v / v)$ (Sigma). The intensities of the reaction bands were analyzed with the Image Gauge System (Fuji, Tokyo, Japan).

Flow Cytometry Analysis

Cell density was adjusted to $1 \times 10^{5}$ cells $/ \mathrm{ml}$, then treated with $10 \mu \mathrm{M}$ PDGF-BB and various concentrations $(0,10,30,90 \mu \mathrm{M})$ of CAPE for 48 or $72 \mathrm{~h}$. Both detached and attached cells were collected, washed with PBS and fixed with ice-cold 70\% ethanol at $4^{\circ} \mathrm{C}$ overnight. Cells were then washed with PBS, incubated with propidium iodide $(40 \mu \mathrm{g} / \mathrm{ml})$ (Molecular Probes, Eugene, Oreg., USA) and DNase-free RNase A $(100 \mu \mathrm{g} / \mathrm{ml})$ for $1 \mathrm{~h}$ at $37^{\circ} \mathrm{C}$ in the dark. The DNA content of the nuclei was analyzed with a flow cytometer (Partec GmbH, Münster, Germany). 
DNA Fragmentation Analysis

HCSMCs were treated with $10 \mu \mathrm{M}$ PDGF-BB and various concentrations of CAPE $(0,3,10,30,90 \mu \mathrm{M})$ for 48 or $72 \mathrm{~h}$. Both detached and attached cells were collected and washed with PBS. The analysis was performed using the Tissue \& Cell Genomic kit (GeneMark, Taiwan) according to the manufacturer's instructions. Fragmented DNA was extracted and electrophoresed on a $1.8 \%$ agarose gel containing $0.1 \mu \mathrm{g} / \mathrm{ml}$ ethidium bromide.

\section{Terminal Deoxynucleotidyl Transferase-Mediated dUTP}

Nick-End Labeling Staining

Cell apoptosis was identified by a TdT-mediated dUTP-biotin nick-end labeling (TUNEL) assay according to the manufacturer's instructions (Roche, USA). Briefly, the cells grown on a coverslip in a 6-well plate were incubated with $10 \mu \mathrm{M}$ PDGF-BB and various concentrations $(0,10,30,90 \mu \mathrm{M})$ of CAPE for 48 or $72 \mathrm{~h}$. The cells were then chilled on ice, washed 3 times with cold $0.3 \%$ Triton-X-100-PBS and fixed in 2\% paraformaldehyde for $30 \mathrm{~min}$ at room temperature. After fixation, the cells were washed 3 times with cold $0.3 \%$ Triton X-100-PBS and coverslip cultures were incubated with a TUNEL reaction mixture in a humidified atmosphere for $60 \mathrm{~min}$ at $37^{\circ} \mathrm{C}$ in the dark. After incubation, the cells were washed 3 times with cold $0.3 \%$ Triton X-100-PBS and then coverslip cultures were counterstained with 4',6'-diamidino-2phenylindole (DAPI) and examined with an LSM 510 confocal microscope (Zeiss, Germany). Quantifications of positive cells in TUNEL staining were performed by taking images in 6 regions of cover slides at a magnification of $400 \times$. The percentages of TUNEL-positive cells per total numbers of cells were counted and analyzed.

\section{Analysis of Mitochondrial and Cytosolic Cytochrome $c$ in}

HCSMCs

Mitochondrial and cytosolic protein fractions of cells were extracted as previously described [12] with some modifications. Briefly, PDGF-BB-stimulated cells after treatment with or without CAPE for 48 or $72 \mathrm{~h}$ were collected and homogenized in icecold $1 \times$ Cytosol Extraction Buffer Mix (BioVision, Mountain View, Calif., USA) with a Protease Inhibitor Cocktail Kit (Ther$\mathrm{mo}$ ) for $10 \mathrm{~min}$ and then centrifuged at $700 \mathrm{~g}$ for $10 \mathrm{~min}$ at $4^{\circ} \mathrm{C}$ to remove the pellets. The supernatants were further centrifuged at $10,000 \mathrm{~g}$ for $30 \mathrm{~min}$ at $4^{\circ} \mathrm{C}$ to separate the cytosolic (in the supernatant) and the mitochondrial (in the pellets) fractions. Finally, the pellets were resuspended with Mitochondrial Extraction Buffer Mix (BioVision) containing Protease Inhibitor Cocktail Kit (Thermo), vortexed for $10 \mathrm{~s}$ to obtain the mitochondrial fraction and stored at $-80^{\circ} \mathrm{C}$ until use. The purity of mitochondrial and cytosolic fractions was verified by immunoblotting for a mitochondrial marker, prohibitin. Fifty micrograms of proteins from each extract was analyzed by Western blotting for cytochrome c. The ratio of cytosolic to total (cytosolic and mitochondrial) abundance of cytochrome $\mathrm{c}$ was determined by densitometry [15].

\section{Statistical Analysis}

Data were expressed as means \pm SDs. The two groups were compared via a two-tailed t test using SAS software. The cell growth and cell migration were analyzed via ANOVA followed by post-hoc analysis. $\mathrm{p}<0.05$ was considered statistically significant.

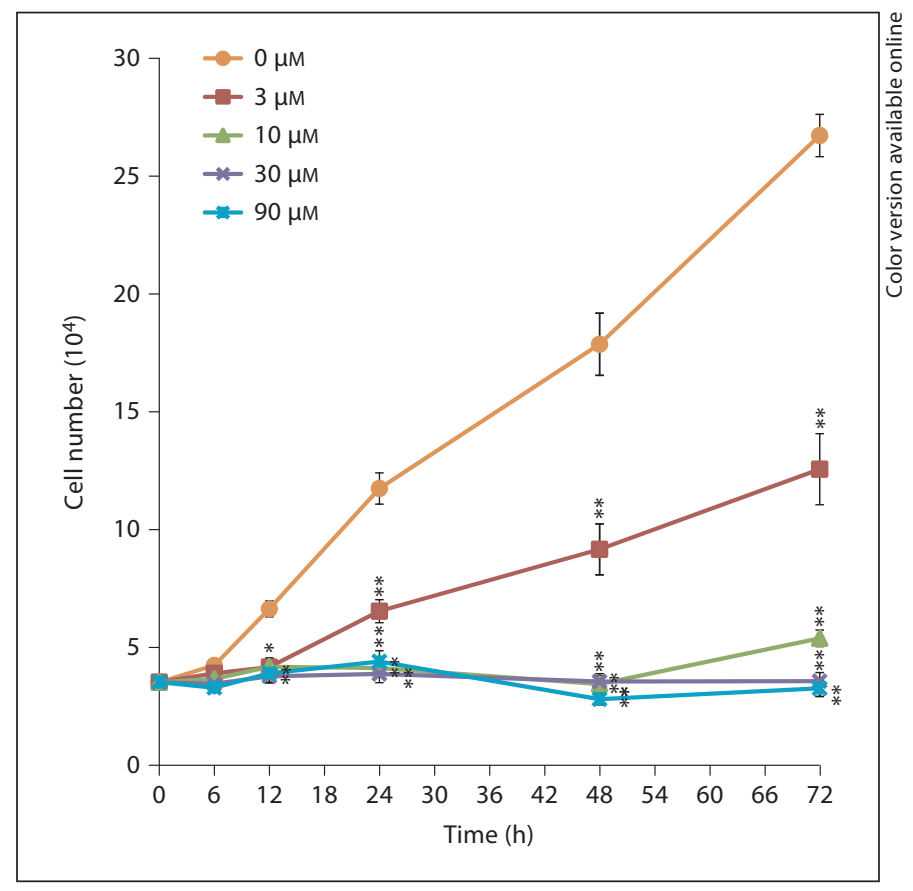

Fig. 1. Inhibition of cell growth of PDGF-BB-stimulated HCSMCs by CAPE. The cells were treated at the indicated concentrations of CAPE and at $10 \mu \mathrm{M}$ PDGF-BB for the indicated times. Cell viability was determined by a trypan blue dye exclusion assay. Data are presented as means \pm SDs of 6 independent experiments. ${ }^{*} \mathrm{p}<0.05,{ }^{* *} \mathrm{p}<0.01$, compared to the control group.

\section{Results}

\section{Inhibition Effect of CAPE on PDGF-BB-Stimulated \\ Proliferation of HCSMCs}

To test the effect of CAPE on cell growth in PDGF-BBstimulated HCSMCs, the growth rate was measured using a trypan blue exclusion assay. The results showed that the cell number of the group without CAPE treatment increased from 12 to $72 \mathrm{~h}$ after stimulation with $10 \mu \mathrm{M}$ PDGF-BB; however, treatment with CAPE reduced or inhibited PDGF-BB-stimulated HCSMC growth (fig. 1).

\section{Inhibition Effect of CAPE on PDGF-BB-Stimulated Migration of HCSMCs}

To assess the effects of CAPE on PDGF-BB-stimulated HCSMC migration, the images of the cell culture after wound-healing experiments were photographed and analyzed at different time intervals. The results showed that the number of migrated HCSMCs was significantly increased at $12 \mathrm{~h}$ and beyond without CAPE treatment. The nonviable cells apparently increased and floated in the 


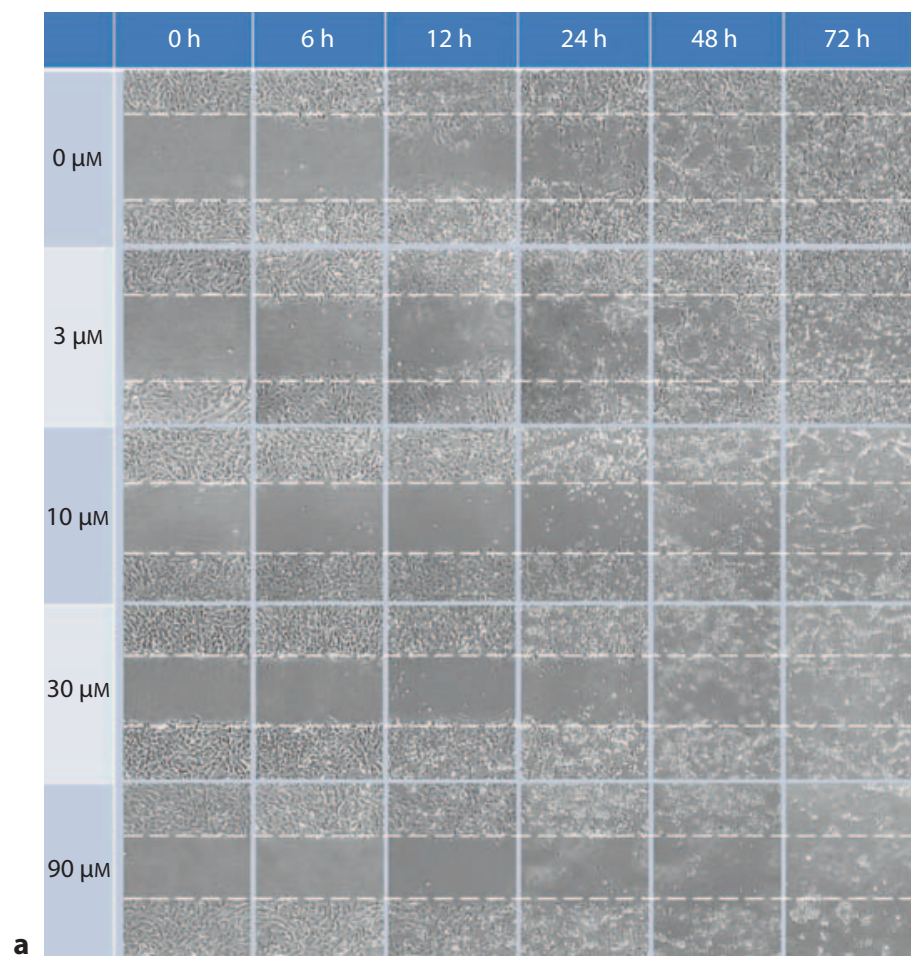

Fig. 2. Inhibition of cell migration of PDGF-BB-stimulated HCSMCs by CAPE. Migration was assessed following mechanical wound healing. a Cell migration was evaluated at $0,6,12,24$, 48 and $72 \mathrm{~h}$ after treatment with various doses of CAPE. Cell migration was strongly inhibited from 12 to $72 \mathrm{~h}$ after CAPE

culture medium from 12 to $72 \mathrm{~h}$ after treatment with 10 , 30 and $90 \mu \mathrm{M}$ CAPE (fig. 2a). Quantitative data indicated that the PDGF-BB-stimulated HCSMC migration was strongly inhibited in the cells treated with 10,30 and 90 $\mu \mathrm{M}$ CAPE (fig. 2b).

\section{Inhibition Effect of CAPE on the Expression}

of Activated AKT1, MEK1, ERK1, but Not on

Phosphorylated IкB

To study the signaling molecules involved in CAPEmediated changes in the proliferation and migration of HCSMCs, we analyzed the cellular expression of phosphorylated AKT1, MEK1, ERK1/2 and IкB (fig. 3a). The decrease of phosphorylated AKT1, MEK1 and ERK1/2 after treatment with higher doses of CAPE for 10, 30 and 60 min indicated that the inhibitory effects of CAPE on the growth and migration of PDGF-BB-stimulated HCSMCs were associated with a downregulation of AKT and MEK signaling pathways. The expression of phosphorylated IкB did not change after treatment with CAPE

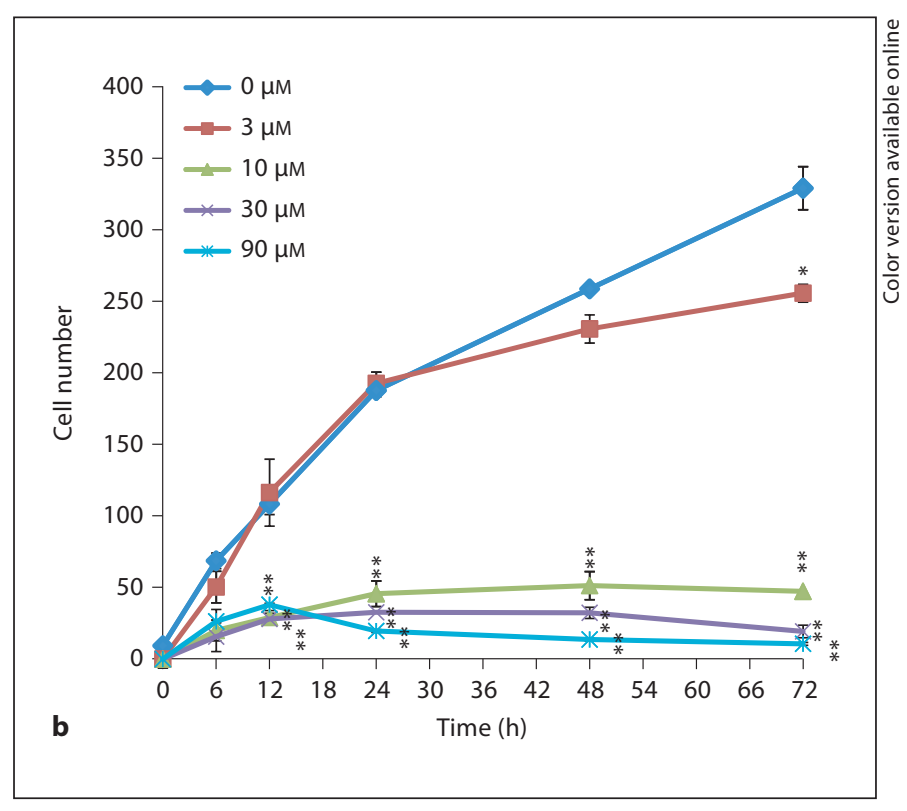

treatment (10-90 $\mu \mathrm{M})$. b Quantitative data showed that cell migration was significantly repressed by CAPE treatment at doses above $10 \mu \mathrm{M}$. Data are presented as means \pm SDs of 6 independent experiments. ${ }^{*} \mathrm{p}<0.05,{ }^{* *} \mathrm{p}<0.01$, compared to the control group.

in PDGF-BB-stimulated HCSMCs. The average quantitative results on the level of a specific protein are presented in figure $3 b$.

\section{Enhancement of the Apoptotic Effect of CAPE on PDGF-BB-Stimulated HCSMCs}

To determine the effect of CAPE on cell apoptosis in PDGF-BB-stimulated HCSMCs, we investigated the apoptotic effects of CAPE by performing a flow-cytometric assay, DNA fragmentation analysis and a TUNEL assay. In flow cytometry, the apoptotic cell population was significantly increased and accumulated at the sub- $\mathrm{G}_{1}$ phase after treatment with 30 or $90 \mu \mathrm{M}$ CAPE for $72 \mathrm{~h}$ (fig. 4a). DNA fragmentation was also observed in the cells at $72 \mathrm{~h}$ after treatment with 30 or $90 \mu \mathrm{M}$ CAPE (fig. $4 \mathrm{~b}$ ). Cell apoptosis was further confirmed by the TUNEL assay. Few to no TUNEL-positive cells were detected in the cells at zero or low-dose CAPE treatment $(10 \mu \mathrm{M})$ (fig. 4c, d). The percentages of TUNEL-positive cells were $42 \pm 3$ and $64 \pm 2 \%$, respectively, after treatment with 30 and 

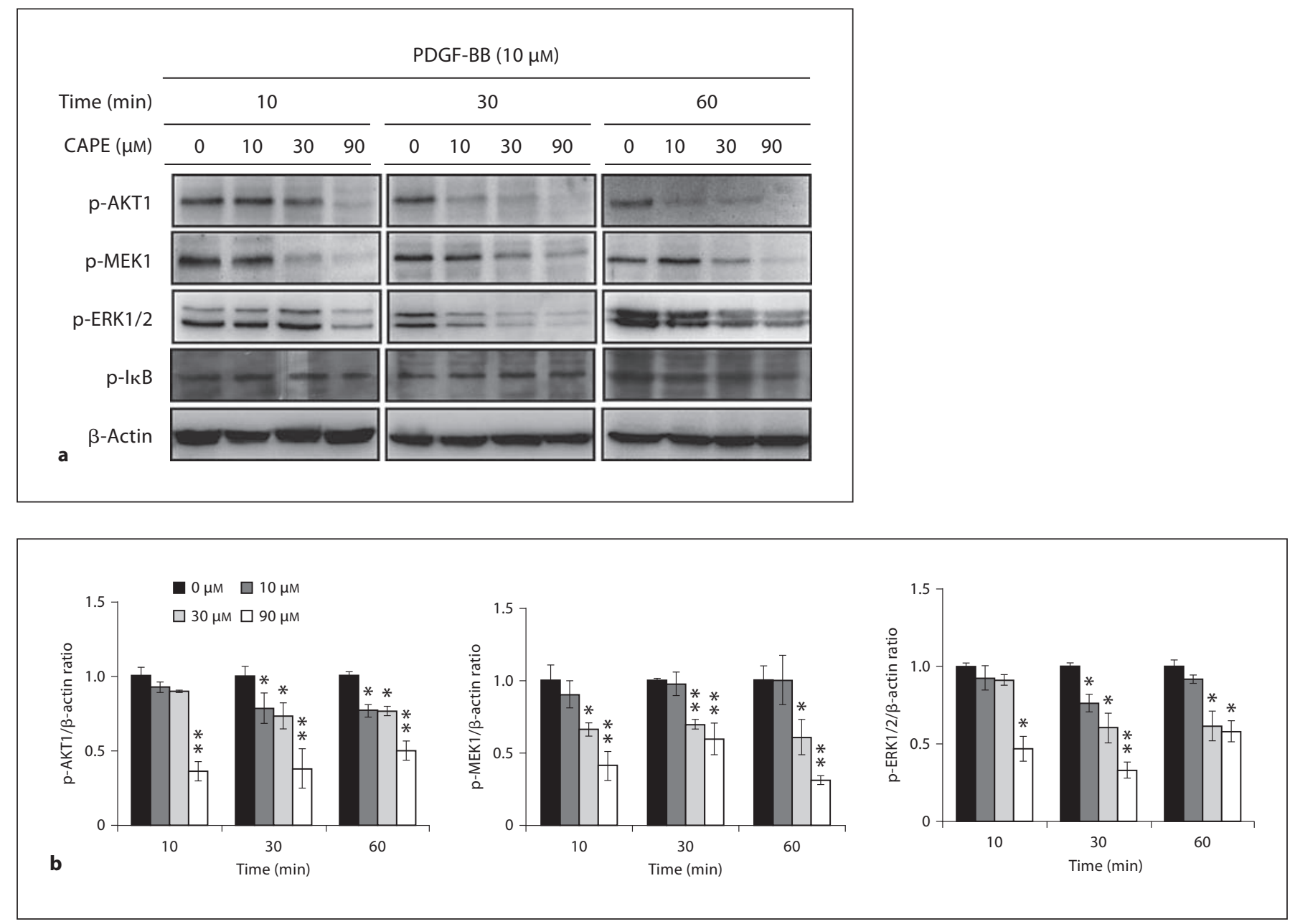

Fig. 3. CAPE inhibited the activation of AKT1, MEK1 and ERK1/2 but displayed no effect on I $\mathrm{B}$ activation in PDGF-BB-stimulated HCSMCs. a Phosphorylated (p) AKT1, ERK1/2, MEK1/2 and ІкB expression was detected by Western blotting using specific antibodies. Phosphorylated AKT1, MEK1 and ERK1/2 cellular expres- sion decreased at $10-90$ min after 30 or $90 \mu \mathrm{M}$ CAPE treatment, whereas phosphorylated IкB expression was not changed. b Quantitative results on the level of specific proteins. ${ }^{*} \mathrm{p}<0.05,{ }^{* *} \mathrm{p}<$ 0.01 , compared to the control group.
$90 \mu \mathrm{M}$ CAPE for $72 \mathrm{~h}$ (fig. 4e, f). These results indicate that CAPE induced apoptosis of the PDGF-BB-stimulated HCSMCs at high concentrations (30 and $90 \mu \mathrm{M}$ ).

\section{Abundance of Mitochondrial and Cytosolic \\ Cytochrome c in HCSMCs}

The release of cytosolic cytochrome $\mathrm{c}$ has been reported as the initiation of apoptosis [16], which triggers the activation of effector caspases [17]. To speculate whether CAPE modulated the apoptotic factors in PDGF-BB-induced HCSMCs, the distribution of cytochrome $\mathrm{c}$ in mitochondrial and cytosolic compartments of HCSMCs was assessed. Immunoblot analysis showed that cytosol- ic cytochrome c increased from about 25 to $90 \%$ after CAPE treatment (fig. 5a, b). These results indicate that CAPE can induce PDGF-BB-triggered cytochrome $c$ release in HCSMCs.

\section{CAPE Induced Proapoptotic and Suppressed \\ Antiapoptotic Effects on Bcl-2 Family Proteins and \\ Caspase Activation}

It has been reported that the integrity of the outer mitochondrial membrane is mediated by Bcl- 2 family proteins in SMCs [18-20]. Since CAPE enhanced cytochrome c release from mitochondria to cytosol, the balance among Bcl-2 family proteins was investigated. Immu- 


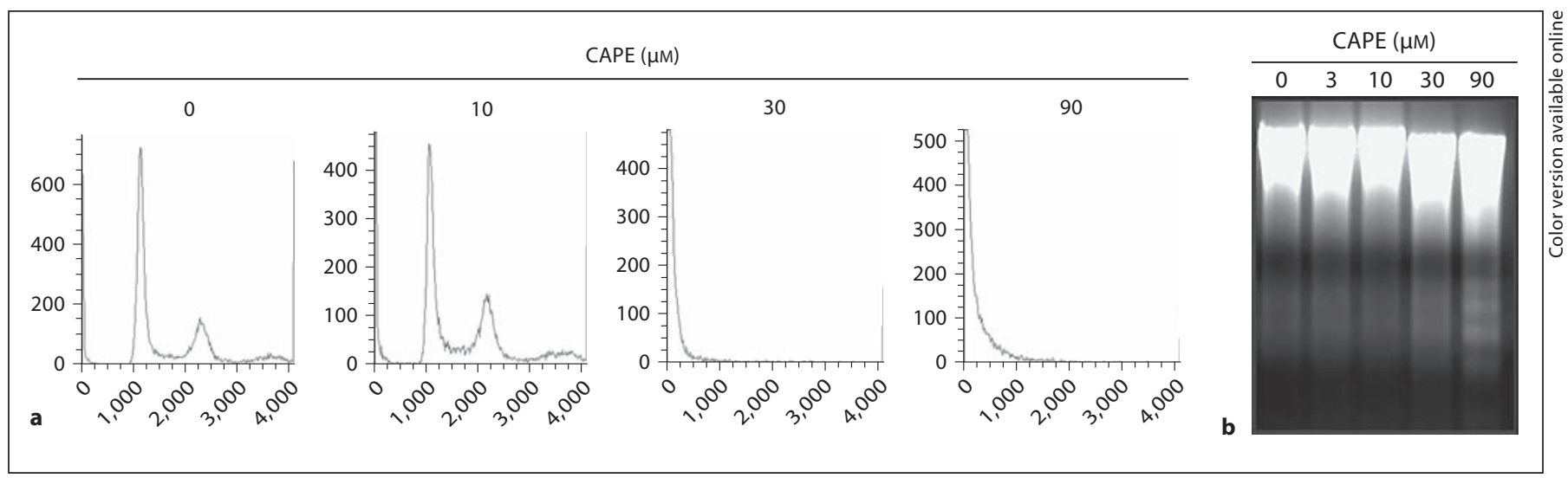

Fig. 4. Effect of CAPE on cell cycle and DNA fragmentation in PDGF-BB-stimulated HCSMCs. a DNA distribution histogram of PDGB-BB-stimulated HCSMCs by flow-cytometric analysis. The sub- $\mathrm{G}_{1}$ peak (apoptotic cells) was observed at $72 \mathrm{~h}$ after 30 or $90 \mu \mathrm{M}$ CAPE treatment. b DNA fragmentation analysis demonstrated that CAPE sensitized apoptotic cells at $72 \mathrm{~h}$ after 30 or 90 $\mu \mathrm{M}$ CAPE treatment. TUNEL assay and DAPI staining (blue fluorescence) to assay the effect of CAPE on cell apoptosis in PDGFBB-stimulated HCSMCs. c, d No TUNEL-positive cells were detected in cells at $72 \mathrm{~h}$ after treatment with 0 and $10 \mu \mathrm{M}$ CAPE. e, f TUNEL-positive cells (green fluorescence) were detected at $72 \mathrm{~h}$ after treatment with 30 and $90 \mu \mathrm{M} \mathrm{CAPE}$. Arrows indicate TUNEL-positive cells. Scale bar: $15 \mu \mathrm{m}$.
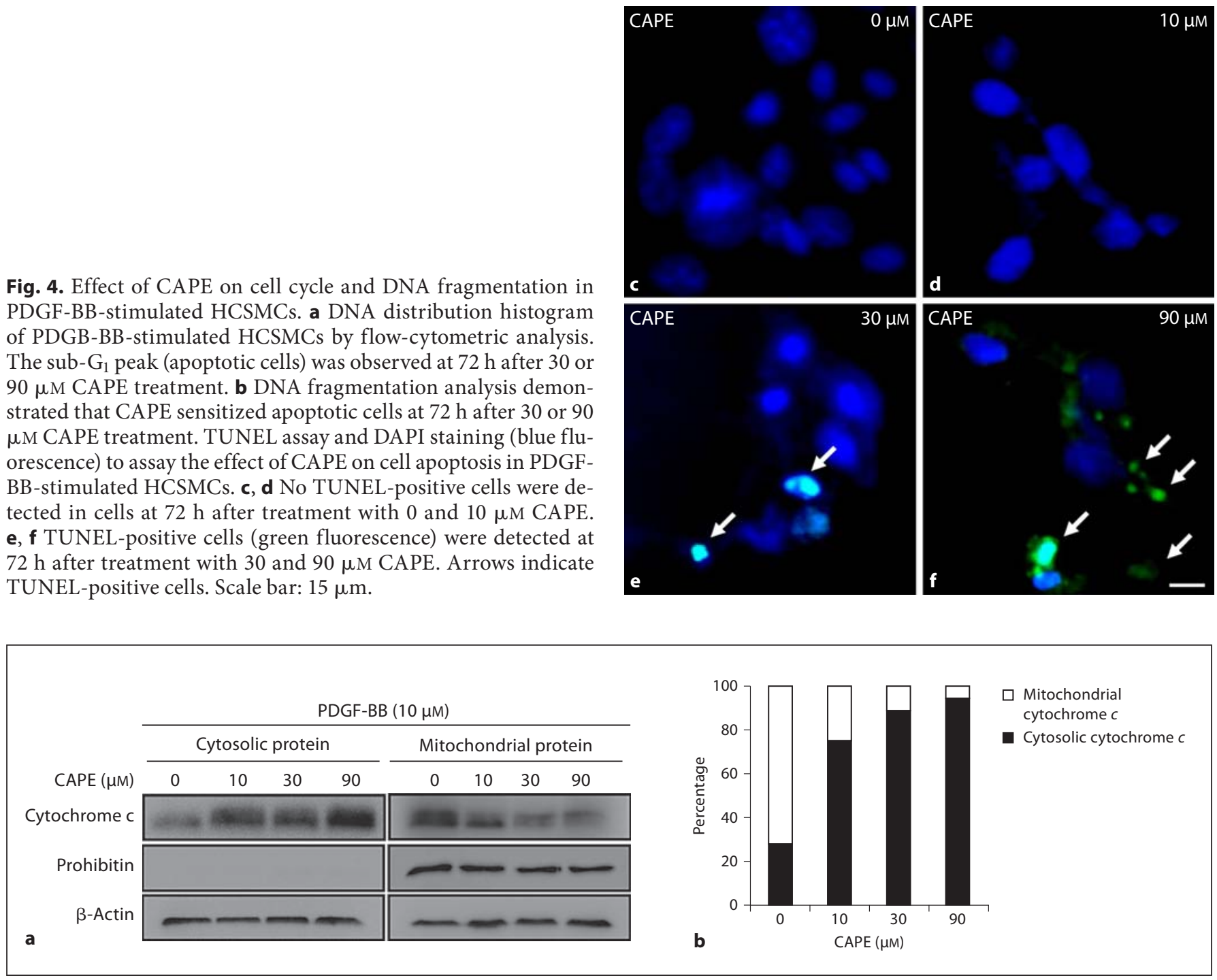

Fig. 5. Effects of CAPE on mitochondrial cytochrome $\mathrm{c}$ release in PDGF-BB-stimulated HCSMCs. a Immunoblotting data indicate that CAPE increased the abundance of cytochrome $\mathrm{c}$ in the cytosolic fraction and decreased its amount in the mitochondrial fraction at $48 \mathrm{~h}$ after treatment. The purity of the mitochondrial and cytosolic protein extracts was confirmed by the mitochondrial marker prohibitin, which was present in the mitochondrial but not in the cytosolic fractions. b Quantitative analysis indicates that the cytosolic fraction of cytochrome $\mathrm{c}$ increased from about 25 to $90 \%$ after CAPE treatment. 
Fig. 6. Immunoblotting analysis of antiapoptotic effects on Bcl-2 family proteins and caspase activation. $\mathbf{a}, \mathbf{b}$ The expression of the antiapoptotic molecule Bcl-2 was downregulated and the proapoptotic molecule Bax was upregulated in cells treated with 30 and $90 \mu \mathrm{M}$ CAPE compared with the non-CAPE-treated cells at $48 \mathrm{~h}$. a, c Moreover, the cellular amount of cleaved caspase- 9 and -3 but not caspase- 8 was significantly increased after 10,30 and $90 \mu \mathrm{M}$ CAPE treatment at $48 \mathrm{~h} .{ }^{*} \mathrm{p}<0.05$, ${ }^{*} \mathrm{p}<0.01$, compared to the control group.
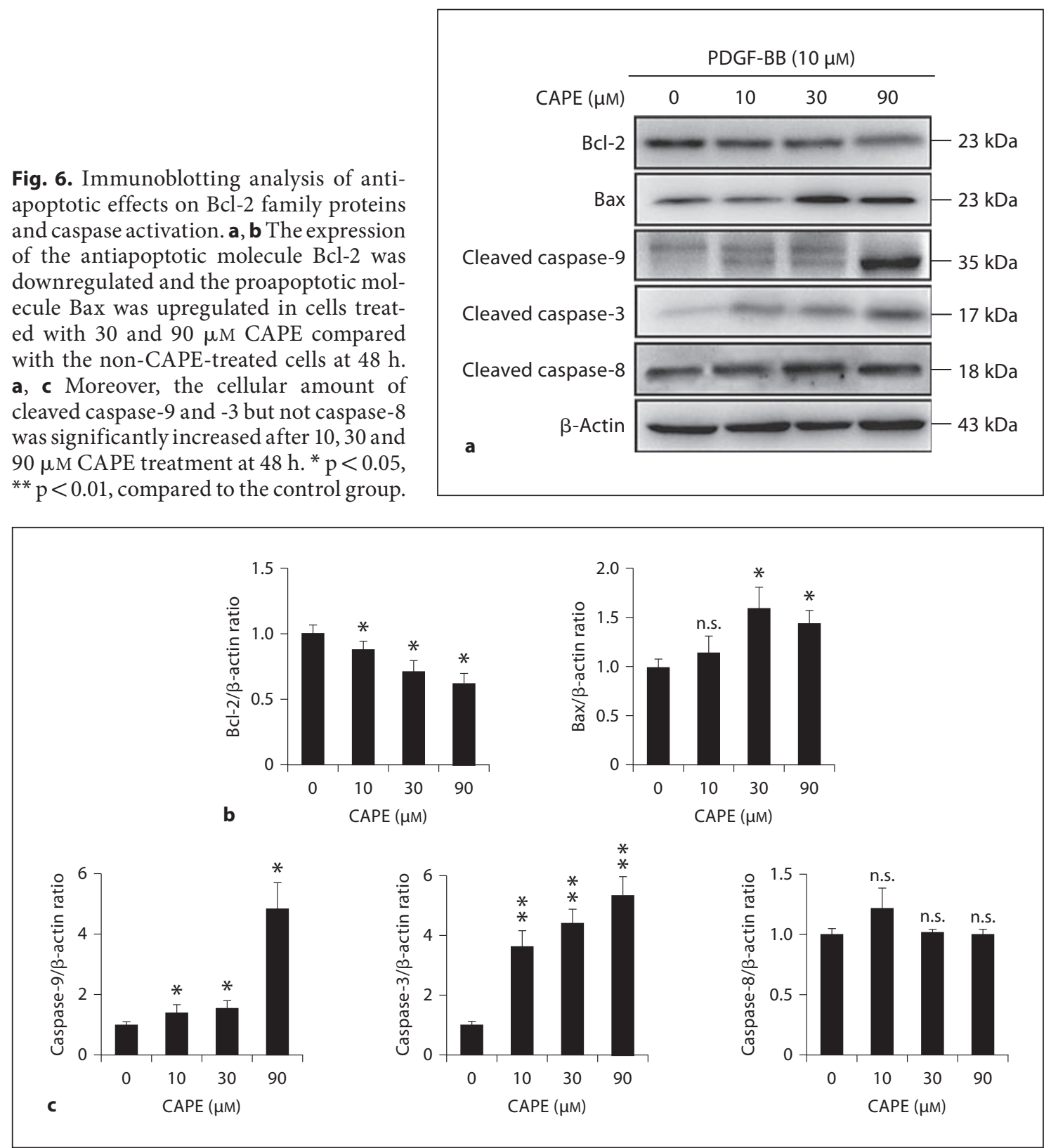

noblotting analyses indicated that expression of the antiapoptotic molecule Bcl-2 decreased and the proapoptotic molecule Bax increased in CAPE-treated cells compared with those in the non-CAPE-treated group at $72 \mathrm{~h}$ (fig. $6 \mathrm{a}$, b). Several key factors in the execution of mitochondrial apoptosis, caspase- 9 and -3 , were activated in the intrinsic pathway (fig. 6a, c). The expression of caspase- 8 , however, was not activated (fig. 6a, c).

\section{Discussion}

Proliferation, migration and high resistance to apoptosis of coronary SMCs play important roles in the development of atherosclerotic diseases and restenosis after angioplasty. A natural compound, rich in polyphenolic constituents, administered via drug-eluting stents, may prevent arterial restenosis. A number of in vitro and in vivo studies on polyphenolic compounds have revealed 
that their beneficial effect on vascular diseases may be due to the modulation of abnormal cell proliferation, migration and apoptosis [21]. The underlying cellular mechanisms, however, have not been elucidated. In this study, we examined the molecular mechanisms of CAPE on the growth, migration and apoptosis of HCSMCs after PDGF-BB stimulation in an in vitro model mimicking the action of HCSMCs triggered in the PDGF-BB-releasing condition after PCI.

Various growth factors released from impaired endothelial cells and recruited platelets and macrophages during vascular injury can trigger SMC proliferation and migration. Some reports demonstrated that proliferation and apoptosis of SMCs are closely related to the activation of NF- $\kappa B ~[13,22]$. However, in our study, no such effects of phosphorylated IкB on SMC proliferation, migration and apoptosis were observed in CAPE-treated cells (fig. 3a). We suggested that CAPE inhibits proliferation and migration, and induces apoptosis via NF- $\kappa \mathrm{B}$-independent pathways [23, 24]. PDGF-BB exerts the most potent mitogenic and inflammatory effects. It has been reported that PDGF-BB can induce both proliferation and directed migration in vitro, activate several signaling cascades, promote cell survival, and inhibit the intrinsic apoptotic pathway [25]. PDGF-BB-stimulated HCSMCs have been suggested to be associated with upregulation of the PI3K/ AKT and ERK signaling pathways [26]. Dephosphorylation of ERK/MAPK signaling molecules induces apoptotic activity. Downregulation of SMC apoptosis is a key contributor to intimal lesions [27]. In this study, we demonstrated that CAPE effectively inhibited proliferation and migration, and induced apoptosis in PDGF-BB-stimulated HCSMCs. Concomitantly, phosphorylated AKT1, MEK1 and ERK1/2 decreased in a dose-dependent manner after CAPE treatment within 10,30 and $60 \mathrm{~min}$ (fig. 3).

Arterial SMCs normally stay in the $\mathrm{G}_{0}$ phase of the cell cycle and keep in a quiescent nonproliferative state. They re-enter the cell cycle after balloon angioplasty; marked induction of cyclins A and E, CDK2 and proliferating cell nuclear antigen protein expression was observed with an increase in the level of CDK2 kinase activity [28]. We have demonstrated that the expressions of cyclin A, cyclin E, CDK2, cyclin D1, CDK4, cyclin B1 and CDK1 decreased in the PDGF-BB-stimulated HCSMCs after CAPE treatment (data not shown). To further investigate the pattern of the antiproliferative effect of CAPE on PDGF-BB-stimulated SMCs, flow-cytometric analysis was performed in this study. The results showed that CAPE treatment at the concentrations of 30 and $90 \mu \mathrm{M}$ for $72 \mathrm{~h}$ resulted in the induction of cell accumulation at the sub- $\mathrm{G}_{1}$ phase. In the meantime, cell apoptosis was also observed by DNA fragmentation and a TUNEL assay (fig. 4,5). Our previous study had indicated that without stimulation of PDGF-BB, cell cycle arrest occurred in the $S$ phase and no apoptosis was found in the cells after CAPE treatment [12]. It has been reported that vascular SMCs from injured and uninjured arteries show different growth properties in cultures [28]. The present study demonstrated that CAPE is more effective at inducing apoptosis in vascular SMCs after growth factor stimulation than in nonstimulated SMCs. We assumed that CAPE can inhibit cell proliferation and migration and induce apoptosis more efficiently by inhibiting signal transduction kinases, thereby activating the caspase pathways.

PDGF-BB can activate the cell-signaling molecules and inhibit the interaction between $\mathrm{Bcl}-2$ and $\mathrm{Bim}, \mathrm{Bcl}-2$ and Bax, thereby inhibiting cell apoptosis [29]. In this study, we demonstrated that treatment of HCSMCs with CAPE after exogenous PDGF-BB stimulation induced apoptosis through the mitochondrion-dependent apoptotic pathway. Its action is accompanied by activation of caspase-3 and caspase-9, downregulation of Bcl-2 and upregulation of Bax in the cells. Caspase- 8 , however, was not activated by CAPE, indicating the death receptor Fas or its ligand FasL was not involved in CAPE-induced $\mathrm{SMC}$ apoptosis. It has been reported that apoptosis can be induced by CAPE, 6 and $20 \mu \mathrm{g} / \mathrm{ml}$, in human leukemic HL-60 cells and mouse epidermal cell line C141 cells, respectively [30,31]. Apparently, CAPE needs a higher dose $(30 \mu \mathrm{g} / \mathrm{ml})$ to induce apoptosis in primary HCSMCs than in cancer cell lines. Further investigation of the in vivo efficiency of CAPE on vascular SMCs in animal injury models should be performed.

\section{Acknowledgements}

This work was supported by research grant TCVGH-T977811 from Taichung Veterans General Hospital and Tunghai University, Taiwan, Republic of China.

References

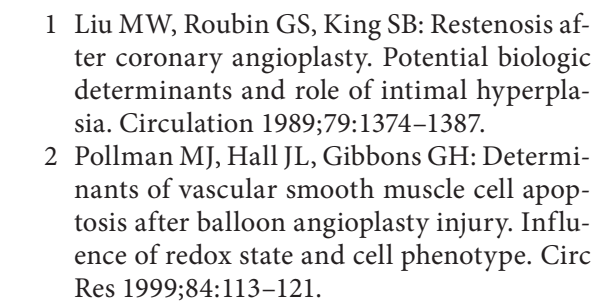

J Vasc Res 2012;49:24-32 
3 Sriram V, Patterson C: Cell cycle in vasculoproliferative diseases: potential interventions and routes of delivery. Circulation 2001;103:2414-2419.

4 Bornfeldt KE, Raines EW, Graves LM, Skinner MP, Krebs EG, Ross R: Platelet-derived growth factor: distinct signal transduction pathways associated with migration versus proliferation. Ann NY Acad Sci 1995;12: 416-430.

$\checkmark 5$ Cospedal R, Abedi H, Zachary I: Platelet-derived growth factor-BB (PDGF-BB) regulation of migration and focal adhesion kinase phosphorylation in rabbit aortic vascular smooth muscle cells: roles of phosphatidylinositol 3-kinase and mitogen-activated protein kinases. Cardiovasc Res 1999;41: 708-721.

$\checkmark 6$ Jawien A, Bowen-Pope DF, Lindner V, Schwartz SM, Clowes AW: Platelet-derived growth factor promotes smooth muscle migration and intimal thickening in a rat model of balloon angioplasty. J Clin Invest 1992; 89:507-511.

7 Jeremias A, Kirtane A: Balancing efficacy and safety of drug-eluting stents in patients undergoing percutaneous coronary intervention. Ann Intern Med 2008; 148:234-238.

$\checkmark 8$ Cherubini A, Vigna GB, Zuliani G, Ruggiero C, Senin U, Fellin R: Role of antioxidants in atherosclerosis: epidemiological and clinical update. Curr Pharm Des 2005;11:2017-2032.

$\checkmark 9$ Kyaw M, Yoshizumi M, Tsuchiya K, Izawa Y, Kanematsu Y, Tamaki T: Atheroprotective effects of antioxidants through inhibition of mitogen-activated protein kinases. Acta Pharmacol Sin 2004;25:977-985.

10 Jaganathan SK, Mandal M: Antiproliferative effects of honey and of its polyphenols: a review.J Biomed Biotechnol 2009;2009:1-13.

-11 Orban Z, Mitsiades N, Burke TR Jr, Tsokos M, Chrousos GP: Caffeic acid phenethyl ester induces leukocyte apoptosis, modulates nuclear factor- $\mathrm{\kappa}$ B and suppresses acute inflammation. Neuroimmunomodulation 2000;7:99-105.
>12 Ho HC, Hsu SL, Ting CT, Kuo CY, Yang VC: Caffeic acid phenethyl ester inhibits arterial smooth muscle cell proliferation and migration in vitro and in vivo using a local delivery system. Cell Mol Biol 2009;55:1161-1167.

13 Maffia P, Ianaro A, Pisano B, Borrelli F, Capasso F, Pinto A, Ialenti A: Beneficial effects of caffeic acid phenethyl ester in a rat model of vascular injury. Br J Pharmacol 2002;136: 353-360.

14 Chen CN, Li YS, Yeh YT, Lee PL, Usami S, Chien S, Chiu JJ: Synergistic roles of plateletderived growth factor-BB and interleukin$1 \beta$ in phenotypic modulation of human aortic smooth muscle cells. Proc Natl Acad Sci USA 2006;103:2665-2670.

$>15$ Liu TJ, Yeh YC, Ting CT, Lee WL, Wang LC, Lee HW, Wang KY, Lai HC: Ginkgo biloba extract 761 reduces doxorubicin-induced apoptotic damage in rat hearts and neonatal cardiomyocytes. Cardiovasc Res 2008;80: 227-235.

16 Liu X, Kim CN, Yang J, Jemmerson R, Wang $\mathrm{X}$ : Induction of apoptotic program in cellfree extracts: requirement for dATP and cytochrome c. Cell 1996;86:147-157.

17 Scorrano L: Opening the doors to cytochrome c: changes in mitochondrial shape and apoptosis. Int J Biochem Cell Biol 2009; 41:1875-1883.

18 Adams JM, Cory S: Bcl-2-regulated apoptosis: mechanism and therapeutic potential. Curr Opin Immunol 2007; 19:488-496.

19 Green DR, Kroemer G: The pathophysiology of mitochondrial cell death. Science 2004; 305:626-629.

20 Saelens X, Festjens N, Vande Walle L, van Gurp M, van Loo G, Vandenabeele P: Toxic proteins released from mitochondria in cell death. Oncogene 2004;23:2861-2874.

-21 Giovannini C, Scazzocchio B, Varì R, Santangelo C, D’Archivio M, Masella R: Apoptosis in cancer and atherosclerosis: polyphenol activities. Ann Ist Super Sanita 2007;43:406416.

22 Hishikawa K, Nakaki T, Fujita T: Oral flavonoid supplementation attenuates atherosclerosis development in apolipoprotein E-deficient mice. Arterioscler Thromb Vasc Biol 2005;25:442-446.
23 Tatetsu H, Okuno Y, Nakamura M, Matsuno F, Sonoki T, Taniguchi I, Uneda S, Umezawa K, Mitsuya H, Hata H: Mol Cancer Ther 2005;4:1114-1120.

-24 Wang C, Fu M, D’Amico M, Albanese C, Zhou JN, Brownlee M, Lisanti MP, Chatterjee VKK, Lazar MA, Pestell RG: Mol Cell Biol 2001;21:3057-3070.

25 Bonni A, Brunet A, West AE, Datta SR, Takasu MA, Greenberg ME: Cell survival promoted by the Ras-MAPK signaling pathway by transcription-dependent and -independent mechanisms. Science 1999;286:13581362 .

26 Li JM, Brooks G: Cell cycle regulatory molecules (cyclins, cyclin-dependent kinases and cyclin-dependent kinase inhibitors) and the cardiovascular system; potential targets for therapy. Eur Heart J 1999;20:406-420.

-27 Andrés V: Control of vascular cell proliferation and migration by cyclin-dependent kinase signalling: new perspectives and therapeutic potential. Cardiovasc Res 2004;63: $11-21$.

28 Walker LN, Bowen-Pope DF, Ross R, Reidy MA: Production of platelet-derived growth factor-like molecules by cultured arterial smooth muscle cells accompanies proliferation after arterial injury. Proc Natl Acad Sci 1986;83:7311-7315.

29 Harada H, Quearry B, Ruiz-Vela A, Korsmeyer SJ: Survival factor-induced extracellular signal-regulated kinase phosphorylates BIM, inhibiting its association with BAX and proapoptotic activity. Proc Natl Acad Sci 2004;101:15313-15317.

30 Chen YJ, Shiao MS, Hsu ML, Tsai TH, Wang SY: Effect of caffeic acid phenethyl ester, an antioxidant from propolis, on inducing apoptosis in human leukemic HL-60 cells. J Agric Food Chem 2001;49:5615-5619.

-31 Nomura M, Kaji A, Ma W, Miyamoto K, Dong Z: Suppression of cell transformation and induction of apoptosis by caffeic acid phenethyl ester. Mol Carcinog 2001;31:8389. 